\title{
MULTICRITERIA OPTIMIZATION OF MANUFACTURING PROCESSES OF THE ROTORS TO OPEN END SPINNING MACHINE
}

\author{
Roman Lorek, Stanisław Płonka
}

\begin{abstract}
$\mathrm{Sum} \mathrm{m}$ a r $\mathrm{y}$
The paper presents Pareto-optimum method and POLOPT computer program enabling, with the use of principle of conversation with computer, assessment of solutions (variants) in the view of two or more criteria (up to 10). The Pareto-optimal set is univariate in a few cases only, and therefore, in remaining cases to selection of the best solution from this set one proposed the distance function. The chosen procedure of the multicriteria optimization was tested on the example of selection of the best variant of the manufacturing process of rotors to the open end spinning machine.
\end{abstract}

Keywords: manufacturing processes, optimization, manufacturing cost, product quality

Wielokryterialna optymalizacja procesów wytwarzania wirnika przędzarki bezwrzecionowej

$$
\text { Streszczenie }
$$

W artykule przedstawiono metodę optimum w sensie Pareto oraz program POLOPT umożliwiający, na zasadzie konwersacji z komputerem, ocenę rozwiązań (wariantów) z uwzględnieniem liczby 2 i większej kryteriów (do 10). Zbiór Pareto-optymalny tylko dla kilku przypadków jest jednowariantowy. Dlatego w pozostałych przypadkach do wyboru rozwiązania najlepszego z tego zbioru zapropo-nowano funkcję dystansową. Opracowaną procedurę optymalizacji wielokryterialnej poddano weryfikacji w procesie doboru najlepszego wariantu wytwarzania wirnika przędzarki bezwrzecionowej.

Słowa kluczowe: procesy wytwarzania, optymalizacja, koszt wytwarzania, jakość wyrobu

\section{Introduction}

Optimization of manufacturing processes occupies a special position in course of optimization of manufacturing activities. The concept of optimization of manufacturing processes should be understood both as optimization of processing conditions (parametric optimization) and optimization of process structure (structural optimization). Optimization of processing conditions fulfils the task complementary to optimization of a structure. These two issues

Address: Prof. Stanisław PŁONKA, Roman LOREK, Ph.D. Eng., University of Bielsko-Biała, Department of Manufacturing Technology and Automation, 43-309 Bielsko-Biała, Willowa 2, Poland, phone: (0-48, 33) 8279 213, e-mail: splonka@ ath.bielsko.pl 
are interrelated: optimization of a structure requires prior assignment of values, close to optimal, to parameters of individual treatments comprising the operations, and these, in turn, comprising the process. Optimization of parameters requires prior optimization of process structure and its individual operations. Solution to the emerging conflict is iteration proceeding, in which usually at the beginning one solves a task of selection of a process structure, and next of the operation close to the optimal (taking typical values of parameters - recommended by producers of cutting tools), and in the next step one performs optimization of the parameters. Then one can go again to more precise selection of the structure, etc. $[1,2]$.

Objective for the purpose of parametric optimization is selection of (among possible to implementation in a given conditions - in an area of feasible solutions, determined by limitations) such values of cutting parameters like: cutting speed $v_{c}$, feed rate $f$ and depth of cut $a_{p}$, which assure the extreme value of assumed criterion of the optimization [3].

Issue of optimization of manufacturing operations parameters has lived to see a rich bibliography, which was discussed in detail in works [3-5]. Whereas, issue of optimization and polyoptimization of manufacturing processes structures was presented so far in a few works only [6-18]. The starting point to the optimization of the structure is determination of a set of solutions (variants) of the process of the analyzed workpiece, assessed in the light of specified criteria.

The objective of this work is to present a procedure of multicriteria optimization of processes structures and its verification on the example of selection of the best variant, with respect to adopted criteria. of the manufacturing process of the rotors to the open end spinning machine.

\section{Method of selection of the optimal variant}

\subsection{Pareto-optimal methods}

Problems of multicriteria optimization of manufacturing processes structure are generally solved in two phases: determining a set of Pareto-optimal solutions and next, selecting the best (optimal) solution from this set [1, 19-21].

To select an optimal variant (solution) one has chosen the Pareto-optimal method, which consists of determination of a set of non-dominated variants (set of compromises) or set of Pareto-optimal variants [1, 19]. Let $\boldsymbol{A}$ denote a feasible set of manufacturing process variants:

$$
A=\left\{a_{1}, a_{2}, \ldots, a_{n}\right\}
$$


and $K^{(d)}-$ set of criteria with deterministic character from 1 to $m$ :

$$
K^{(d)}=\left\{k_{l}^{(d)}, k_{2}^{(d)}, \ldots, k_{m}^{(d)}\right\}
$$

The table with assessments of the variants with respect to individual criteria has a form of:

$$
\left[\begin{array}{l}
k_{11}^{(d)}, k_{12}^{(d)}, \ldots, k_{1 i}^{(d)}, \ldots, k_{1 s}^{(d)} \\
k_{21}^{(d)}, k_{22}^{(d)}, \ldots ., k_{2 i}^{(d)}, \ldots, k_{2 s}^{(d)} \\
\ldots \ldots \ldots \ldots \ldots \ldots \ldots \ldots \ldots \ldots \ldots \ldots \\
k_{j 1}^{(d)}, k_{j 2}^{(d)}, \ldots, k_{j i}^{(d)}, \ldots, k_{j s}^{(d)} \\
\ldots \ldots \ldots \ldots \ldots \ldots \ldots \ldots \ldots \ldots . . \\
k_{m 1}^{(d)}, k_{m 2}^{(d)}, \ldots, k_{m i}^{(d)}, \ldots, k_{m s}^{(d)}
\end{array}\right]
$$

where: $k_{j i}^{(d)}=k_{j}^{(d)}\left(a_{i}\right)$ - assessment of $i$-th variant according to $j$-th criterion, $j=1, \ldots, m$.

Such a variant, which simultaneously extremizes each criterion, is taken as the ideal variant of the manufacturing process.

In a case of minimization, $a_{i}^{(i d)}$ is taken as the ideal variant if:

$$
\bigwedge_{a_{i} \in A} \bigvee_{a_{i}^{(i d)} \in A} \mathbf{k}^{(d)}\left(a_{i}^{(i d)}\right) \leq \mathbf{k}^{(d)}\left(a_{i}\right)
$$

where: $\mathbf{k}^{(d)}\left(a_{i}\right)$ - a vector of assessments of $i$-th variant with respect to each from the criteria.

Because these criteria are usually in conflict, the ideal variant does not exist in such a case.

As non-dominated variant is taken such a variant, for which none criterion can be improved without simultaneous worsening of at least one criterion from the remaining ones.

In a case of minimization, $a_{i}^{(n d)}$ is a non-dominated variant, if:

$$
\left.\bigwedge_{j}\right\rceil \bigvee_{\mathbf{k}^{(d)}\left(a_{i}\right) \in K^{(d)}} k_{j}^{(d)}\left(a_{i}\right) \leq k_{j}^{(d)}\left(a_{i}^{(n d)}\right) \wedge \bigvee_{j} k_{j}^{(d)}\left(a_{i}^{(n d)}\right)<k_{j}^{(d)}\left(a_{i}\right)
$$

A set of non-dominated variants $Z A$ is also called a set of compromise variants or a set of Pareto-optimal variants. To the set $Z A$ is assigned a set of criteria - compromise criteria $Z K \in K^{(d)}$. 
A set of Pareto-optimal variants usually contains many variants, and among them, generally the best (optimal) variant $a_{i}^{(\text {opt) }} \in Z A$ is chosen on the basis of the additional criterion.

A task of multicriteria Pareto optimization of manufacturing process variants can be formulated as follows-determine a set of compromise assessments:

$$
\left.Z K=\left\{\mathbf{k}^{(d)}\left(a_{i}^{(n d)}\right): \bigwedge_{j}\right\rceil \mathbf{k}_{\mathbf{k}^{(d)}\left(a_{i}\right) \in K^{(d)}} k_{j}^{(d)}\left(a_{i}\right) \leq k_{j}^{(d)}\left(a_{i}^{(n d)}\right) \wedge \bigvee_{j} k_{j}^{(d)}\left(a_{i}^{(n d)}\right)<k_{j}^{(d)}\left(a_{i}\right)\right\}(6)
$$

and assigned to it set of Pareto-optimal variants:

$$
Z A=\left\{a_{i}^{(n d)}: \boldsymbol{k}^{(d)}\left(a_{i}^{(n d)}\right) \in Z K \wedge a_{i}^{(n d)} \in A\right\}
$$

Variant $a_{i}^{(n d)}$ constitutes solution of multicriteria Pareto optimization task if the corresponding vector of the criteria $\mathbf{k}^{(d)}\left(a_{i}^{(n d)}\right)$ is the smallest vector in sense of the partial ordering.

In this formulation one adopted that all the criteria should be minimized. If in the task of multicriteria optimization one should maximize the criterion $k_{j}^{(d)}\left(a_{i}\right)$, such task can be reduced to the task of minimization, changing sign of the criterion.

$$
\max _{j} k_{j i}^{(d)}=-\min _{j}\left(-k_{j i}^{(d)}\right)
$$

To identify the set of Pareto-optimal variants one made use of specially written in Pascal code computer program called POLOPT. The program enables, on the base of conversation with computer, determination of a set of Paretooptimal variants, from a set of feasible variants consisting of maximally 100 variants, assessed maximally with respect to 10 criteria each. Developed in such way program enables determination of the Pareto-optimal set of variants with respect to any number of criteria from the interval between 2 and 10.

The program consist of the following modules: generation of the criteria set, reading of criteria set, selection of criteria to determination of Pareto set, determination of Pareto set, sorting, reviewing and printing of the Pareto set.

\subsection{Selection of the best solution with use of distance function}

Methods of distance function, in their classic approach, enable determination of a single compromise assessment, what usually leads to determination of a single compromise variant. The obtained result depends on the implemented norm and preference of criteria specified by experts. Big 
number of different criteria of the assessment, which characterize variants, makes one have to deal with vector indicators of quality. In situation when some of these indicators are minimized and other maximized, and having in mind that majority of these indicators is expressed in various units, the problem of correct selection of the best variant (solution) is difficult [21]. For independence from influence of different units of individual criteria, and taking into account that the set of criteria comprises assessments both to minimization and to maximization, one has developed a distance function $f_{d(i)}$ having the following form:

$$
f_{d(i)}=\sqrt{\sum_{j=1}^{m}\left[d_{i(j)}-d_{i d(j)}\right]^{2}} \rightarrow \min
$$

where: $d_{i(j)}$ - normalized value of $j$ criterion for individual variants (solutions), $d_{i d(j)}$ - normalized value of $j$ criterion for ideal point.

The best variant from Pareto-optimal set of solutions is such a variant, for which the distance function $f_{d(i)}$ achieves the minimum.

\section{Example of selection of optimal variant of manufacturing process of the rotor to open end spinning frame}

\subsection{Preparation of optimization proceeding}

In the PW12 open end spinning machine as a raw material to production of rotors was used $\mathrm{AlCu} 4 \mathrm{Mg}$ aluminum alloy in form of extruded bars in condition of natural precipitation hardening, which resulted in large waste (about $60 \%$ ). Rotors in the spinning machine operate with rotational speed from 300 to 400 revs/s (18 000 to $24000 \mathrm{rpm})$ and should fulfill predetermined requirements concerning quality of manufacturing, i.e.: low roughness of internal surfaces $R a=0.08-0.16 \mu \mathrm{m}$, very low value of axial and radial run-out on all end faces and diameters above $40 \mathrm{~mm}-\Delta B \leq 0,050 \mathrm{~mm}$ and high durability. Moreover, they should undergo dynamic balancing, when assembled with elastic bearing and race, at rotational speed of $n=200 \mathrm{revs} / \mathrm{s}$, while value of unbalance should not exceed $e_{r} \leq 0,05 \mu \mathrm{m}$ [2]. The shape of the single-piece rotor and consisting of a few components is presented in the Fig. 1.

On base of observations of spinning machine in operational conditions it is evident that the rotor belongs to the most often replaced elements of defiberingtwisting heads, and simultaneously to the most expensive. Big wear of the rotors is result of production process of yarn [2].

To increase durability of rotors at specific costs of production, one made selection of material and form of a semi-finished product, as well as a type of surface and finish treatments, with respect to fulfillment of high quality 
requirements at the lowest manufacturing costs. Taking into account design and geometry of rotors (Fig. 1), seven types of aluminum alloys in nine different forms of semi-products were taken into considerations.
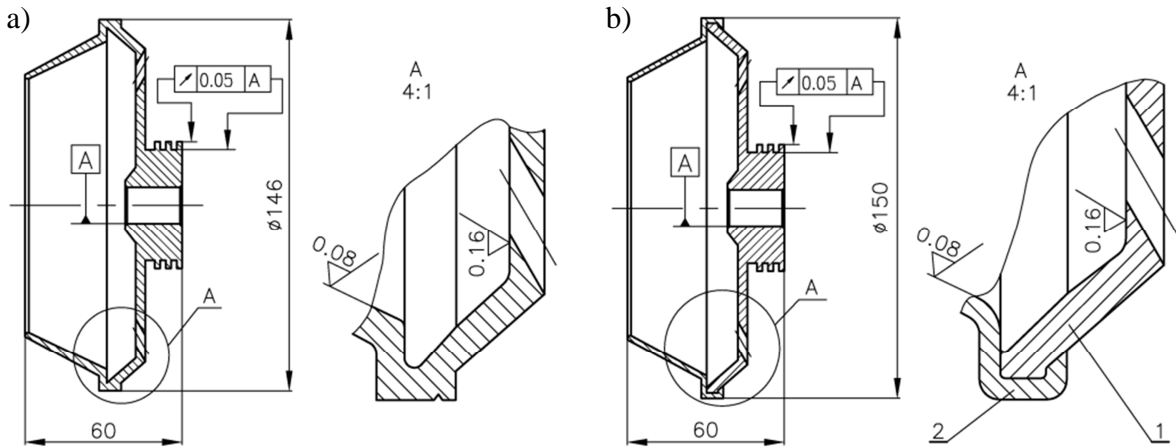

Fig. 1. Rotor: a) single-piece rotor, b) rotor composed of two components: disc (1), cone (2) from $A l M g 2.5$ plate plastic formed by spinning, connected together in clenching operation

Within the set of feasible variants of manufacturing process of rotors to the open end spinning machine one isolated nine sub-groups: $A 1, A 2, A 3, A 4, A 5$, $A 6, A 7, A 8, A 9$, differing in form of semi-product, which are presented in Tables 1 and 2 [17].

For sub-groups $A 1 ; A 2 ; A 3 ; A 4 ; A 5 ; A 6 ; A 7 ; A 8 ; A 9$, of the variants of manufacturing process of the rotor one anticipated three combinations of surface and finishing treatment:

1 - grinding with corundum abrasive cloth of HTJ-13-3 type with grain size of 150 , and next with grain size of 220 and polishing with felt buffing wheel impregnated with abrasive compound of Z-50 type,

2 - grinding with corundum abrasive cloth of HTJ-13-3 type with grain size of 150 , and next with grain size of 220 , and electrolytic oxidation,

3 - grinding with corundum abrasive cloth of HTJ-13-3 type with grain size of 150 , and next grain size of 220 , electrolytic oxidation, grinding with abrasive cloth having grain size of 240, grinding with abrasive cloth having grain size of 360 , and grinding with corundum abrasive paper of PS20 type having grain size of 600 .

In the sub-group $A 8$ and $A 9$ of manufacturing variants of the rotor, due to high surface roughness after electrolytic oxidation, one implemented additional operation of grinding with abrasive cloth having grain size of 120, prior operations of grinding with abrasive cloth having grain size 240 and 360, as well as corundum abrasive paper of PS20 type with grain size of 600 . 
Table 1. Characteristics of semi-products for rotors

\begin{tabular}{|c|c|c|c|}
\hline $\begin{array}{l}\text { Alphanumeric } \\
\text { denomination }\end{array}$ & Variants & $\begin{array}{c}\text { Marking with chemical } \\
\text { symbols }\end{array}$ & Shape of the semi-product \\
\hline EN AW-2024 & $\begin{array}{l}\text { I } \\
\text { II } \\
\text { III }\end{array}$ & $\mathrm{AlCu} 4 \mathrm{Mg} 1$ & $\begin{array}{c}\text { Extruded rod } \\
\phi 150 \times 64.5 \mathrm{~mm}\end{array}$ \\
\hline EN AW-6082 & $\begin{array}{l}\mathrm{IV} \\
\mathrm{V} \\
\mathrm{VI} \\
\end{array}$ & AlSilMgMn & $\begin{array}{l}\text { Extruded rod } \\
\phi 150 \times 64.5 \mathrm{~mm}\end{array}$ \\
\hline EN AW-2618A & $\begin{array}{l}\text { VII } \\
\text { VIII } \\
\text { IX }\end{array}$ & $\mathrm{AlCu} 2 \mathrm{Mg} 1.5 \mathrm{Ni}$ & Die hammer forging $\phi 155 \times 70 \mathrm{~mm}$ \\
\hline EN AW-2014 & $\begin{array}{l}\mathrm{X} \\
\mathrm{XI} \\
\mathrm{XII} \\
\end{array}$ & $\mathrm{AlCu} 4 \mathrm{SiMg}$ & Die hammer forging $\phi 155 \times 70 \mathrm{~mm}$ \\
\hline EN AW-6082 & $\begin{array}{l}\text { XIII } \\
\text { XIV } \\
\text { XV } \\
\end{array}$ & AlSilMgMn & Die hammer forging $\phi 155 \times 70 \mathrm{~mm}$ \\
\hline EN AW-45000 & $\begin{array}{c}\text { XVI } \\
\text { XVII } \\
\text { XVIII }\end{array}$ & AlSi6Cu4 & $\begin{array}{l}\text { Casting from sand mould } \\
\phi 153 \times 91 \mathrm{~mm}\end{array}$ \\
\hline EN AW 45000 & $\begin{array}{l}\text { XIX } \\
\text { XX } \\
\text { XXI }\end{array}$ & AlZn9Si7 & $\begin{array}{l}\text { Casting from sand mould } \\
\qquad 153 \times 91 \mathrm{~mm}\end{array}$ \\
\hline $\begin{array}{l}\text { EN AW-2024 } \\
\text { EN AW-5052 }\end{array}$ & $\begin{array}{l}\text { XXII } \\
\text { XXII } \\
\text { XXIV }\end{array}$ & $\begin{array}{l}\text { AlCu4Mg1 } \\
\text { AlMg2.5 }\end{array}$ & $\begin{array}{l}\text { Disc made from extruded rod } \phi 155 \times 33 \\
\text { mm, while the cone plastic formed by } \\
\text { spinning from metal plate with } \\
\text { dimensions of } 195 \times 195 \times 2 \mathrm{~mm}\end{array}$ \\
\hline $\begin{array}{l}\text { EN AW-2618A } \\
\text { EN AA-5052 }\end{array}$ & $\begin{array}{l}\text { XXV } \\
\text { XXVI } \\
\text { XXVII }\end{array}$ & $\begin{array}{l}\text { AlCu2Mg1.5Ni } \\
\quad \text { AlMg2.5 }\end{array}$ & $\begin{array}{l}\text { Disc made from die forging } \phi 155 \times 38 \\
\text { mm, while the cone plastic formed by } \\
\text { spinning from metal plate with } \\
\text { dimensions of } 195 \times 195 \times 2 \mathrm{~mm}\end{array}$ \\
\hline
\end{tabular}

Table 2. Characteristic of semi-product's form for rotors

\begin{tabular}{|c|c|}
\hline $\begin{array}{l}\text { Sub-group } \\
\quad A 1, A 2\end{array}$ & $\begin{array}{l}\text { Rotors from these sub-groups were made from semi-product in form } \\
\text { of an extruded bar from } A l C u 4 M g 1 \text { alloy; i.e. in condition of natural } \\
\text { precipitation hardening (ta) and from a extruded bar from AlSilMgMn alloy } \\
\text { in condition of artificial precipitation hardening (tb). }\end{array}$ \\
\hline $\begin{array}{l}\text { Sub-group } \\
A 3, A 4, A 5\end{array}$ & $\begin{array}{l}\text { Rotors from these sub-groups were made from semi-product in form of die } \\
\text { forgings, made from } \mathrm{AlCu} 2 \mathrm{Mg} 1.5 \mathrm{Ni} ; \mathrm{AlCu} 4 \mathrm{SiMg} \text {; } A l \mathrm{Si} \mathrm{MgMn} \text {, aluminum } \\
\text { alloys, hammer forged, and next artificially precipitation hardened (tb). }\end{array}$ \\
\hline $\begin{array}{r}\text { Sub- } \\
\text { A6 }\end{array}$ & $\begin{array}{l}\text { Rotors from these sub-groups were made from semi-product in form } \\
\text { of a sand mould castings, from } \mathrm{AlSi} 6 \mathrm{Cu} 4 ; \mathrm{AlZn} 9 \mathrm{Si} \text { aluminum castings. }\end{array}$ \\
\hline $\begin{array}{l}\text { Sub-group } \\
\quad A 8, A 9\end{array}$ & $\begin{array}{l}\text { Rotors from these sub-group were made as assembled from two elements: disc } \\
\text { and cone, while the disc was turned from an extruded bar from } \mathrm{AlCu} A \mathrm{Mg} I \\
\text { aluminum alloy (sub-group } \mathrm{A} 8 \text { ) and from a die forging from } \mathrm{AlCu} \mathrm{CMg} 1.5 \mathrm{Ni} \\
\text { aluminium alloy, hammer forged (sub-group } \mathrm{A} 9 \text { ), whereas the cone in a both } \\
\text { sub-groups was plastic formed by spinning on mandrel, material of the cone: } \\
\text { metal plate from } \mathrm{AlMg} 2.5 \text { alloy, thickness } 2 \mathrm{~mm} \text {. }\end{array}$ \\
\hline
\end{tabular}




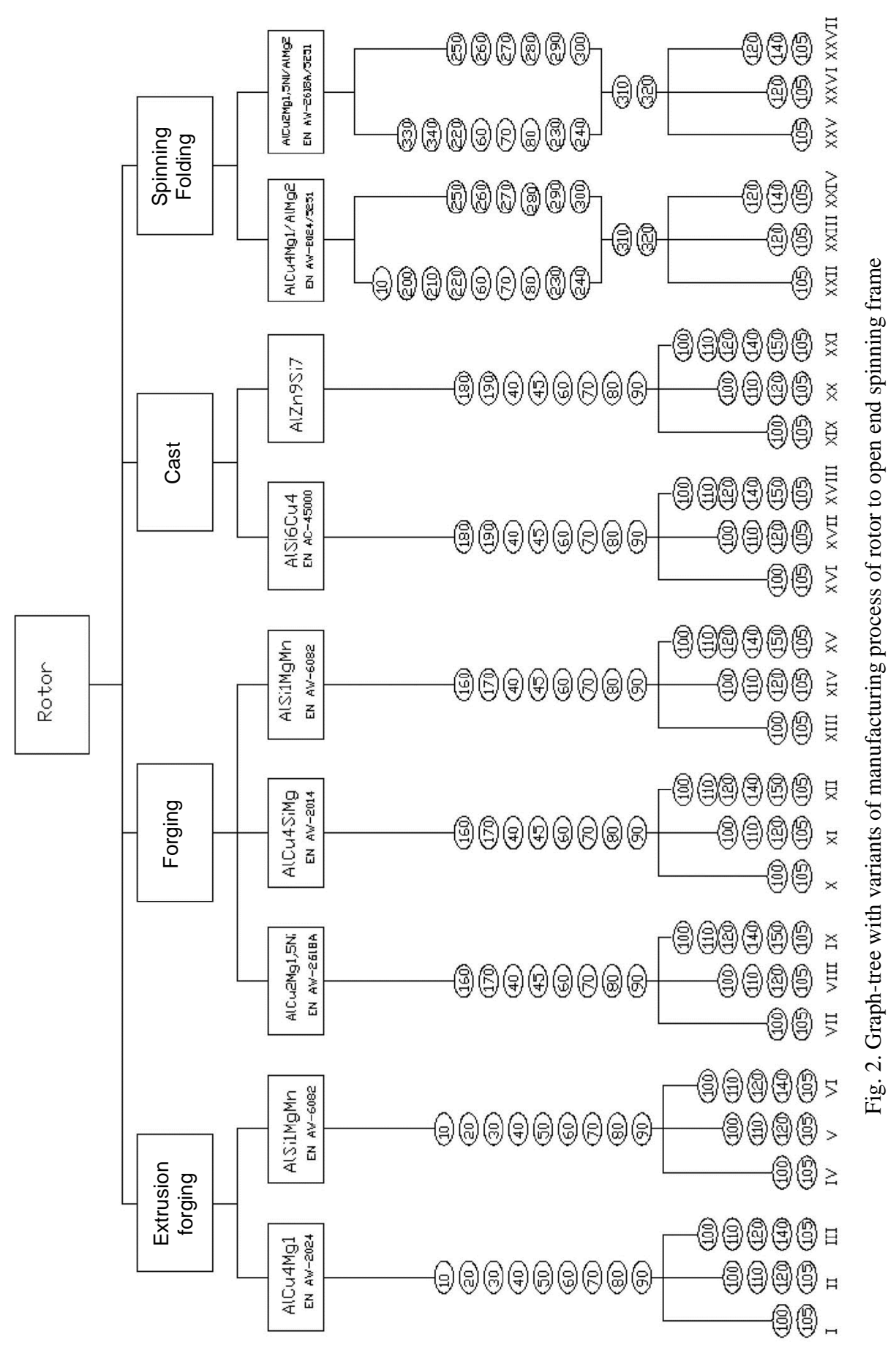


To improve durability of rotors at a given manufacturing costs, while maintaining performance characteristics, one developed and analyzed 27 variants of the manufacturing process of the rotor to open end spinning frame, which are presented with use of the graph-tree (Fig. 2) and described in Table 3.

Table 3. Description of the graph-tree with variants of the manufacturing process of the rotor

\begin{tabular}{|c|c|c|}
\hline $\begin{array}{l}\text { No. of } \\
\text { oper. }\end{array}$ & Name of operation & Workstation \\
\hline 10 & Cutting material to dimension ,x” & Band-saw SBA421/S \\
\hline 20 & Turning external surfaces and drilling hole $\phi 11$ & Turning lathe TZC-32N1 \\
\hline 30 & $\begin{array}{l}\text { Drilling hole } \phi 50, \text { turning external surfaces, turning internal } \\
\text { surfaces, boring recess and collector groove. Boring hole } \\
\phi 12 \text { and reaming the hole to } \phi 12.2 \mathrm{U} 7\end{array}$ & Turning lathe TZC-32N1 \\
\hline 40 & Turning hub to $\phi 47$ and grooves on width of $2.5 \mathrm{~mm}$ & Turning lathe TZC-32N1 \\
\hline 45 & $\begin{array}{l}\text { Finish turning external surfaces, boring internal surfaces, } \\
\text { and deepening the collector groove }\end{array}$ & Turning lathe TZC-32N1 \\
\hline 50 & $\begin{array}{l}\text { Finish turning external surfaces, and boring internal conical } \\
\text { surface together with the collector groove }\end{array}$ & Turning lathe TZC-32N1 \\
\hline 60 & Inter-operational control & $\begin{array}{c}\text { Bench testing centres and } \\
\text { sensing element }\end{array}$ \\
\hline 70 & Drilling twelve holes $\phi 6$ & Drilling machine $2 \mathrm{H}-125$ \\
\hline 80 & Rounding off sharp edges & Grinding station \\
\hline 90 & Grinding with abrasive cloth having grain size 150 and 220 & Special grinder \\
\hline 100 & $\begin{array}{l}\text { Polishing with the felt disc impregnated with an abrasive } \\
\text { compound }\end{array}$ & Special polisher \\
\hline 105 & Dynamic balancing & Dynamic balancer \\
\hline 110 & Final inspection & $\begin{array}{l}\text { Inspection-Measuring } \\
\text { station }\end{array}$ \\
\hline 120 & Electrolytic oxidation & Anodizing station \\
\hline 130 & Final inspection & $\begin{array}{l}\text { Inspection-Measuring } \\
\text { station }\end{array}$ \\
\hline 140 & $\begin{array}{l}\text { Grinding with an abrasive cloth having grain size of } 240 \\
\text { and } 360\end{array}$ & Special grinder \\
\hline 150 & Grinding with an abrasive paper having grain size of 600 & Special grinder \\
\hline 160 & $\begin{array}{l}\text { Turning end face and external diameter of hub and face of } \\
\text { disc, drilling hole } \phi 11\end{array}$ & Turning lathe TZC-32N1 \\
\hline 170 & $\begin{array}{l}\text { Rough and shape turning external surface, facing end face, } \\
\text { rough and shape boring internal surface of a hole, turning } \\
\text { collector groove, reboring a collector groove and other } \\
\text { internal surfaces, boring a hole } \phi 102 \text {, finish boring internal } \\
\text { cone with collector groove, chamfering a hole and reboring } \\
\text { the hole } \phi 12.2 \text { U7 }\end{array}$ & Turning lathe TZC-32N1 \\
\hline 180 & $\begin{array}{l}\text { Cutting off skinhead, drilling hole } \phi 11 \text {, reaming hole to } \\
\phi 12.2 \mathrm{U} 7 \text {, turning external diameter of a hub and facing } \\
\text { the end face of hub. }\end{array}$ & Turning lathe TZC-32N1 \\
\hline 190 & $\begin{array}{l}\text { Boring internal surface with collector groove, turning } \\
\text { external surface, finish boring internal surfaces and the } \\
\text { collector groove }\end{array}$ & Turning lathe TZC-32N1 \\
\hline
\end{tabular}


Table 3. (contd) Description of the graph-tree with variants of the manufacturing process of the rotor

\begin{tabular}{|c|l|c|}
\hline $\begin{array}{c}\text { No. of } \\
\text { oper. }\end{array}$ & \multicolumn{1}{|c|}{ Name of operation } & Workstation \\
\hline 200 & $\begin{array}{l}\text { Initial turning hub, turning cone, spot drilling with rigid } \\
\text { drill } \phi 20, \text { drilling hole } \phi 11, \text { turning hub }\end{array}$ & Turning lathe TZC-32N1 \\
\hline 210 & $\begin{array}{l}\text { Facing end face, turning internal surface with recess, } \\
\text { turning collector groove, reaming hole } \phi 12.2 ~ U 7, \\
\text { chamfering hole }\end{array}$ & Turning lathe TZC-32N1 \\
\hline 220 & Turning external surface of hub and disc, turning grooves & Turning lathe TZC-32N1 \\
\hline 230 & $\begin{array}{l}\text { Grinding with abrasive cloth having grain size of 150 and } \\
220\end{array}$ & Special grinder \\
\hline 240 & $\begin{array}{l}\text { Polishing internal surface of disc with felt disc impregnated } \\
\text { with abrasive compound Z-50 }\end{array}$ & Special polisher \\
\hline 250 & $\begin{array}{l}\text { Cutting plate from AlMg2.5 alloy having thickness of 2 mm } \\
\text { to size 195x195mm }\end{array}$ & Mechanic guillotine Q11 \\
$2 \times 2000$
\end{tabular}

\subsection{Determining Pareto-optimal set of variants}

To determine the set of Pareto-optimal variants one made use of specially developed POLOPT computer program, written in the Pascal code. Assessment criteria in this algorithm are treated as equally important (on equal importance right). Using individual modules of the program one created the set of criteria for 27 variants of the manufacturing process of the rotor. Next, one assigned to the criteria the index $\max$, if the criterion in the multicriteria optimization task should be maximized, or min, if a given criterion in the multicriteria optimization task should be minimized.

In the next step, one determined Pareto-optimal set for the analyzed set of feasible variants, consisting of 27 variants of the manufacturing process of the rotor. Pareto-optimal set with respect to the following six criteria: unit manufacturing cost $K_{w}$, surface roughness expressed with parameters $S_{p}$ and $S_{q}$, 
maximal micro-hardness $\mu H V$, hardening depth of a surface layer or depth of an oxide layer $g_{u}$, and the coefficient of break spinning efficiency $W_{s z}$, consisting of 16 variants.

To Pareto-optimal variants belong the following variants: I; IV; VIII; IX; X; XIII; XIV; XV, XVI; XVII, XVIII; XIX; XX; XXI; XXII; XXVII.

Value of the criteria for the Pareto-optimal set of variants is specified in Table 4.

Table 4. Pareto-optimal set for six criteria: $K_{w}, S_{p}, S_{q}, \mu H V, g_{u}, W_{s z}$

\begin{tabular}{|c|c|c|c|c|c|c|c|}
\hline No. & $\begin{array}{c}\text { Number } \\
\text { of variant }\end{array}$ & $\begin{array}{c}\boldsymbol{K}_{\boldsymbol{w}}, \\
\mathbf{P L N} / \mathbf{p i e c e}\end{array}$ & $\begin{array}{c}\boldsymbol{S}_{\boldsymbol{p}}, \\
\boldsymbol{\mu m}\end{array}$ & $\begin{array}{c}\boldsymbol{S}_{\boldsymbol{q}}, \\
\boldsymbol{\mu m}\end{array}$ & $\begin{array}{c}\boldsymbol{\mu H V}, \\
\mathbf{M P a}\end{array}$ & $\begin{array}{c}\boldsymbol{g}_{\boldsymbol{u}}, \\
\boldsymbol{\mu m}\end{array}$ & $\boldsymbol{W}_{\boldsymbol{s z}}$ \\
\hline 1 & I & 151.20 & 2.33 & 0.19 & 1.530 & 15 & 1.0 \\
\hline 2 & IV & 137.50 & 0.79 & 0.19 & 1.010 & 15 & 1.0 \\
\hline 3 & VIII & 223.70 & 5.67 & 1.35 & 3.870 & 110 & 0.7 \\
\hline 4 & IX & 232.05 & 1.06 & 0.36 & 4.560 & 105 & 1.0 \\
\hline 5 & X & 103.85 & 2.13 & 1.01 & 1.510 & 15 & 1.0 \\
\hline 6 & XIII & 102.40 & 0.86 & 0.18 & 1080 & 15 & 1.0 \\
\hline 7 & XIV & 222.40 & 5.68 & 1.49 & 7080 & 120 & 0.9 \\
\hline 8 & XV & 229.90 & 1.61 & 0.80 & 7280 & 110 & 1.0 \\
\hline 9 & XVI & 91.10 & 2.29 & 0.20 & 1140 & 10 & 1.0 \\
\hline 10 & XVII & 210.10 & 17.01 & 5.37 & 3150 & 80 & 0.5 \\
\hline 11 & XVIII & 271.65 & 4.20 & 1.35 & 3440 & 70 & 1.0 \\
\hline 12 & XIX & 88.50 & 5.33 & 0.34 & 1360 & 20 & 1.0 \\
\hline 13 & XX & 208.50 & 12.32 & 4.04 & 2940 & 80 & 0.6 \\
\hline 14 & XXI & 216.30 & 6.90 & 2.05 & 3390 & 70 & 1.0 \\
\hline 15 & XXII & 125.10 & 1.29 & 0.17 & 1480 & 15 & 1.0 \\
\hline 16 & XXVII & 232.20 & 1.04 & 0.38 & 4420 & 105 & 0.9 \\
\hline
\end{tabular}

\subsection{Selection of the best variant with use of the distance function}

In the next stage of the proceeding, deterministic values of criteria for assessments for the Pareto-optimal set were reduced to space of $\langle 0 ; 1\rangle$, making use of the following normalization function:

$$
d_{i(j)}=\frac{k_{i j}-\min _{1 \leq l \leq n}\left(k_{l j}\right)}{\left[\max _{1 \leq l \leq n}\left(k_{l j}\right)-\min _{1 \leq l \leq n}\left(k_{l j}\right)\right]}
$$

In result of the normalization one obtained the following values of the criteria from space $<0 ; 1>$ for individual variants constituting the Pareto-optimal set (Table 5). 
Table 5. Normalized values of criteria of Pareto optimal set

\begin{tabular}{|c|c|c|c|c|c|c|c|}
\hline No. & $\begin{array}{c}\text { Number of } \\
\text { variant }\end{array}$ & $\begin{array}{c}\boldsymbol{K}_{\boldsymbol{w}}, \\
\mathbf{P L N}, \mathbf{p i e c e}\end{array}$ & $\begin{array}{c}\boldsymbol{S}_{\boldsymbol{p}}, \\
\boldsymbol{\mu m}\end{array}$ & $\begin{array}{c}\boldsymbol{S}_{\boldsymbol{q}}, \\
\boldsymbol{\mu m}\end{array}$ & $\begin{array}{c}\boldsymbol{\mu H V}, \\
\mathbf{M P a}\end{array}$ & $\begin{array}{c}\boldsymbol{g}_{\boldsymbol{u}}, \\
\boldsymbol{\mu m}\end{array}$ & $\boldsymbol{W}_{\boldsymbol{s z}}$ \\
\hline 1 & $\mathrm{I}$ & 0.436326 & 0.094945 & 0.003846 & 0.082935 & 0.045455 & 1.000000 \\
\hline 2 & $\mathrm{IV}$ & 0340988 & 0.000000 & 0.003846 & 0.000000 & 0.045455 & 1.000000 \\
\hline 3 & VIII & 0.940849 & 0.300863 & 0.226923 & 0.0456140 & 0.909091 & 0.400000 \\
\hline 4 & IX & 0.998956 & 0.016646 & 0.036538 & 0.566188 & 0.863636 & 1.000000 \\
\hline 5 & X & 0.106820 & 0.082614 & 0.161538 & 0.078745 & 0.045455 & 1.000000 \\
\hline 6 & XIII & 0.096729 & 0.004316 & 0.001923 & 0.011164 & 0.045455 & 1.000000 \\
\hline 7 & XIV & 0.931802 & 0.301480 & 0.253846 & 0.968102 & 1.000000 & 0.800000 \\
\hline 8 & XV & 0.983994 & 0.050555 & 0.132692 & 1.000000 & 0.909091 & 1.000000 \\
\hline 9 & XVI & 0.018093 & 0.092478 & 0.005769 & 0.020734 & 0.000000 & 1.000000 \\
\hline 10 & XVII & 0.846207 & 1.000000 & 1.000000 & 0.341308 & 0.636364 & 0.000000 \\
\hline 11 & XVIII & 0.898747 & 0.210234 & 0.226923 & 0.387560 & 0.545455 & 1.000000 \\
\hline 12 & XIX & 0.000000 & 0.279901 & 0.032692 & 0.055821 & 0.090909 & 1.000000 \\
\hline 13 & XX & 0.832985 & 0.710850 & 0.744230 & 0.307814 & 0.636363 & 0.200000 \\
\hline 14 & XXI & 0.889352 & 0.376695 & 0.361538 & 0.379585 & 0.545454 & 1.000000 \\
\hline 15 & XXII & 0.254697 & 0.030826 & 0.000000 & 0.074960 & 0.045456 & 1.000000 \\
\hline 16 & XXVII & 1.000000 & 0.015413 & 0.543860 & 0.543860 & 0.863636 & 0.800000 \\
\hline
\end{tabular}

In the successive step, taking into consideration fact whether the criterion is to be maximized or minimized, one determined co-ordinates of the ideal point:

$$
d_{i d(j)}=(0 ; 0 ; 0 ; 1 ; 1 ; 1)
$$

To select the best variant from Pareto-optimal set one used the distance function described by the formula (9). In case of the six criteria, shape of the function is as follows:

$$
f_{d(i)}=\sqrt{\left[d_{i(1)}-d_{i d(1)}\right]^{2}+\left[d_{i(2)}-d_{i d(2)}\right]^{2}+, \ldots,+\left[d_{i(6)}-d_{i d(6)}\right]^{2}}
$$

The value of the distance function $f_{d(i)}$ for sixteen Pareto-optimal variants is presented in Table 6 .

As the best variant is taken such a variant for which the value of the distance function $f_{d(i)}$ is the lowest. In our case, the best variant is the variant $X V$, for which $f_{d(X V)}=0.998335$.

For the best variant, values of the criteria are as follows: $K_{w}=229,90$ PLN/piece; $S_{p}=1.61 \mathrm{~mm} ; S_{q}=0.86 \mathrm{~mm} ; m H V=7280 \mathrm{MPa} ; g_{u}=110 \mathrm{~mm}$; $W_{s z}=1,0$. 
Table 6. Value of the distance function $f_{d(i)}$ for sixteen Pareto-optimal variants

\begin{tabular}{|c|c|c|c|c|c|}
\hline No. & $\begin{array}{c}\text { Number of the } \\
\text { variant }\end{array}$ & $\begin{array}{c}\text { Distance from ideal } \\
\text { variant }\end{array}$ & No. & $\begin{array}{c}\text { Number of the } \\
\text { variant }\end{array}$ & $\begin{array}{c}\text { Distance from ideal } \\
\text { variant }\end{array}$ \\
\hline 1 & I & 1.396988 & 9 & XVI & 1.402810 \\
\hline 2 & IV & 1.423884 & 10 & XVII & 2.069341 \\
\hline 3 & VIII & 1.300483 & 11 & XVIII & 1.218661 \\
\hline 4 & IX & 1.098323 & 12 & XIX & 1.340647 \\
\hline 5 & X & 1.3425519 & 13 & XX & 1.714706 \\
\hline 6 & XIII & 1.377800 & 14 & XXI & 1.098885 \\
\hline 7 & XIV & 1.031795 & 15 & XXII & 1.353764 \\
\hline \hline 8 & XV & 0.998335 & 16 & XXVII & 1.126289 \\
\hline
\end{tabular}

\section{Summary}

In multicriteria designing of manufacturing processes of products similar to ones already being in production, where generally it is possible to determine with sufficient accuracy values of criteria taken to assessment, good results of selection of the best variant can be obtained in the two-stage procedure of multicriteria optimization. In the first stage, the procedure comprises determination of the set of non-dominated variants (the set of Pareto-optimal variants), while in the second stage - using the distance function, selection of the best variant from this set. The advantage of this procedure is that in both stages of optimization proceeding one uses the same criteria of assessment. Thus, it becomes unnecessary to define an additional (most often new) criterion, what greatly facilitates selection of the best solution.

\section{References}

[1] J. SZADKOWSKI: Metodologiczne problemy polioptymalizacji w budowie maszyn. Mat. XXI Sympozjum „Modelowanie w Mechanice”. PTMTS, Gliwice-Wisła 1982.

[2] S. PŁONKA: Metody oceny i wyboru optymalnej struktury procesu technologicznego. Rozprawy naukowe 48. Budowa i eksploatacja maszyn. Politechnika Łódzka, Filia w Bielsku-Białej, Bielsko-Biała 1998.

[3] J. SZWABOWSKI: Polioptymalizacja parametryczna wielozabiegowych operacji toczenia zarysów złożonych. Prace Naukowe 504, Politechnika Szczecińska, Szczecin 1993.

[4] B. PYTLAK: Optymalizacja wielokryterialna operacji toczenia stali $18 \mathrm{HGT}$ w stanie zahartowanym. Rozprawa doktorska. Akademia Techniczno-Humanistyczna w Bielsku-Białej, Bielsko-Biała 2007.

[5] J. SZWABOWSKI, M. ZASADA: Use of genetic algorithm in parametric multiobjective optimization of Multi-tool operations with simultaneously active tools. Advances in Manufacturing Science and Technology, 23(1999)2, 71-97. 
[6] J. SZADKOWSKI: Projektowanie optymalnych procesów technologicznych w oparciu o metodę programowania dynamicznego. Mechanik, 32(1969)5.

[7] J. SZADKOWSKI: Polioptymalizacja w projektowaniu operacji obróbki skrawaniem. Advances in Manufacturing Science and Technology, 4(1980)3/4.

[8] M. HUCZEK: Wpływ czynników procesu produkcyjnego na wskaźniki techniczno-ekonomiczne przedsiębiorstwa produkującego wyroby śrubowe. Praca doktorska. Politechnika Krakowska, Kraków 1980.

[9] S. PŁONKA, J. SZADKOWSKI: Polioptymalizacja procesów technologicznych wrzecion przędzalniczych. Zeszyty Naukowe Politechniki Łódzkiej 493, Mechanika 73, Łódź 1985.

[10] A.I. KONDAKOW, N.A. JASTREBOWA: Tiechniko-ekonomiczeskije kriterii optimalnosti tiechnołogiczeskich processow. Maszynostrojenije, (1987)1.

[11] E.W. RYŻOW, W.I. AWERCZENKOW: Optimizacyja tiechnołogiczeskich processow miechaniczeskoj obrabotki. Naukowa Dumka, Kiew 1989.

[12] J. SZADKOWSKI: Optymalizacja strukturalna procesów obróbki skrawaniem. Mat. VI Krajowej Konferencji pt. „Postępy w teorii i technice obróbki materiałów”. IOS, Kraków 1990.

[13] J. SZADKOWSKI: Model matematyczny strukturalnej i parametrycznej optymalizacji wielonarzędziowych procesów obróbki skrawaniem. Archiwum Technologii Budowy Maszyn, 9(1992).

[14] J. SZADKOWSKI: Artificial intelligence approach to structural and parametrical optimization of multi-tool-machining processes. Gepgyartastechnologia, 9-10(1992).

[15] J. SZADKOWSKI, S. PŁONKA: Machining process optimization considering wear resistance of manufactured elements. Mat. III Międzynarodowego Sympozjum INSYCONT. IPBM AGH i SEM KBM PAN, Kraków 1990.

[16] A. BREIING, R. KNOSALA: Bewerten technischen Systeme (Theoretische und methodische grundlagen bewertungstechnischer Entscheidungshilfen). SpringerVerlag, Berlin-Heidelberg 1997.

[17] R. LOREK: Optymalizacja wielokryterialna procesów wytwarzania rotorów przędzarek. Rozprawa doktorska. Akademia Techniczno-Humanistyczna w BielskuBiałej, Bielsko-Biała 2009.

[18] S. PŁONKA: Wielokryterialna optymalizacja procesów wytwarzania części maszyn. WNT, Warszawa 2010.

[19] A. OSYCZKA: Multicriterion optimization in engineering with FORTRAN program. Ellis Horwood, John Wiley, New York 1984.

[20] H. ESCHENAUER, J. KOSKI, A. OSYCZKA: Multicriteria design optimization. Springer-Verlag, Berlin 1990.

[21] J. MONTUSIEWICZ: Ewolucyjna analiza wielokryterialna w zagadnieniach technicznych. IPPT PAN, Warszawa 2004. 